\title{
TOTAL QUALITY MANAGEMENT: A STUDY OF PROCESSING THE QUALITY OF 99 BRAND COFFEE PRODUCT
}

\author{
Muhammad Zakki \\ Universitas Sunan Giri Surabaya, Indonesia \\ muhzakki@unsuri.ac.id
}

\begin{abstract}
This study aims to see how the total quality management (TQM) method plays a role in processing 99 coffee products in the Mandiri Mukmin Cooperative. In this study using total qualit management theory and qualitative research. The determination of informants in this study was determined in advance. Data collection was carried out using in-depth interview techniques which were conducted in a structured manner. The data analysis technique starts with doing data reduction, then presenting the data and then drawing conclusions. The data validity technique used the source triangulation technique by comparing the data obtained from each informant. Based on the data analysis carried out, the following conclusions are produced: 1) The implementation of total quality management (TQM) in processing 99 coffee products at the Mukmin Mandiri cooperative is in the packing process which still uses human labor. 2) In controlling the quality of coffee raw materials, the quality of processing is measured from the production process to the application of TQM for coffee products which includes product design, taste, and market service. 3) There are still various kinds of obstacles and problems faced in the TQM process of processing coffee products, namely in the production process the machines used are still not fully manufactured. A space or place to produce at the SME or Home Industry level.
\end{abstract}

Keywords: Total Quality Management, Coffee Production Process

\section{INTRODUCTION}

Coffee drinks have become one of the most popular and sought after drinks in the world. Identical to the bitter taste which is actually addictive for most people. Over time and the rapid spread of coffee beans to all corners of the world, the tradition of drinking coffee originating from the western world has finally been adapted by people in Indonesia. Coffee became known in Indonesia in 1696 when the Mayor of Amsterdam, 
Nicholas Witsen, ordered the commander of the Dutch troops on Malabar Beach, Adrian Van Ommen to bring coffee beans to Batavia.

Arabica coffee was first grown and developed in the eastern area of Jatinegara which is now better known as coffee. Not long after that, coffee became the main trading commodity of the VOC. Javanese coffee at that time was so famous in Europe that Europeans called a cup of coffee a cup of Java. In Western countries, drinking coffee in the morning has even become a kind of ritual and culture. It's not complete when starting an activity without sipping a cup of coffee. Even in America, coffee has become a traditional drink for the people. Coffee is a menu for morning, afternoon and evening drinks. There is the term coffee morning in the community which means it is the right time to chat while enjoying the aroma and taste of coffee (Sara Perry, 1991). The habit of drinking coffee spreads throughout the world, including Indonesia. Coffee is not just a drink to relieve sleepiness, but has turned into a lifestyle for the world community and even Indonesia. All circles and all walks of life love to sip this black drink because it smells and tastes amazing. Modern coffee shops and roadside coffee shops can be easily found in Indonesia.

The coffee processing industry is always increasing every year. The demand for coffee in the domestic and international markets is very high. In the domestic market, for example, the level of domestic coffee consumption is at least 3.5 million to 4 million sacks or the equivalent of 240,000 tons to 270,000 tons. In addition, the annual development of the area of coffee land in Indonesia is considered to strengthen the coffee processing industry, both small and medium scale (MSMEs) and export-oriented companies (Setiawan \& Komara, 2020).

In this study, taking a sampling of cooperative-owned coffee companies, namely 99 coffee products are coffee products produced by the Mukmin Mandiri cooperative. A cooperative engaged in industrial-production processes agricultural products such as spices which are even made from agricultural crops, soybeans which are produced into soy sauce and coffee. However, this research focuses more on how the coffee processing management is. Many companies face sharp global competition in today's era, this is a sign that the more rapid business growth that encourages each company to always give the best of what they produce, the longer the problems faced by the company are getting wider. and complex. These problems stems from a basic economic problem, namely regarding the allocation of limited resources, while on the other hand the company will grow and develop.

With these circumstances, the company must have the ability to maintain or maintain the continuity of the system in the production process, especially in TQM (total quality management) or integrated quality management, so that the resulting quality has high competitiveness. If the implementation of the production process system at TQM is disrupted, the process of achieving company goals will be hampered and will be 
detrimental to the Company. In terms of the TQM system, paying attention to and maintaining product quality is a very important role in supporting the continuity of a company in global competition. For this reason, the author is interested in doing research related to processing 99 coffee with the total quality management (TQM) method. Furthermore, in this study, the research question is: What is the total quality management method in processing 99 coffee production at the Mukmin Mandiri cooperative?

\section{LITERATURE REVIEW}

\section{Total Quality Management (TQM)}

Total Quality Management (TQM) is a management approach that first appeared in the United States, but was later organized and implemented in several Japanese companies. TQM was pioneered by two well-known experts in Japan and in the United States, namely Edward W Deming and Joseph M. Juran.

Organizations that adopt the concept of Total Quality Management see quality as something that is defined by their customers. Customers are considered as evaluators of the quality of a product or service and the institution itself would not be able to survive without them. Based on a study of TQM, products or services that only meet the standards set by the manufacturer will not guarantee sales. Therefore, organizations must use various means to investigate or study customer requirements, then translate them into new, innovative products or services.

TQM as well as quality also has different definitions. According to Garrison (2000) "constraints are anything that hinders you from getting what you want". Therefore, management based on Theory of Constraints is a key success factor. Companies are required to be able to overcome obstacles so that their managerial performance can be better so that they do not interfere with the company's survival. One of the tools considered to help improve managerial performance in achieving the goal of increasing profit is TQM.

The success or failure of implementing TQM is largely determined by the competence of the company's human resources to make it happen. Thus, it can be concluded that TQM is a tool used by the management of a company that involves all personnel in the company in making continuous improvements to products, services, environment related to company products, and company management through innovative scientific methods.

\section{Principles of Total Quality Management}

The principle of TQM is to improve managerial performance in managing the company in order to increase company income. There are several advantages of 
companies applying the principles of quality control described by Ishikawa (1992) in his book, including:

1. Quality control makes it possible to build quality at every step of the production process in order to produce a product that is $100 \%$ defect free,

2. Quality control allows the company to find errors or failures before they turn into a disaster for the company,

3. Quality control allows product design to follow customer requirements efficiently so that products are always made according to customer choice,

4. Quality control can help companies find production data that is wrong.

TQM is also used to improve the company's competitive position in the market and as a tool to increase the ability to produce quality quality output. "A quality product that is able to meet the needs and satisfaction of consumers in a sustainable manner (sustainable satisfaction) will lead to sustainable purchases which in turn can increase the productivity of the company to reach economies of scale with the result of reduced production costs" (Ibrahim, 2000).

The quality improvement carried out by the company is none other than aimed at increasing the company's income and the ultimate goal is to increase the company's profit so that the company can continue to run and stay alive in today's increasingly tight trade competition. Quality improvements can also enhance the company's image in the eyes of customers. The following is a diagram showing the role of quality improvement in a company to improve its competitive position in the trading market and increase accuracy in producing damage-free products.

The advantages of companies that implement TQM are:

1. TQM develops the concept of quality with a totality approach. Quality when viewed from a consumer's point of view is defined as conformity. Quality requirements are imprinted on consumer needs and wants. In the total concept, consumers are not only buyers but can be interpreted as the next process, namely the party that determines the requirements and craves for satisfaction and at the same time as producers who should meet the requirements in order to provide satisfaction. In this case, quality is not viewed in a narrow sense in terms of the product produced, but must also be seen as a whole aspect of the company.

2. The existence of changes and improvements continuously by implementing TQM companies are required to always learn and change to improve or enhance their abilities,

3. The existence of preventive efforts means that from product design, production process to the final product producing good products without defects (zero defects) so that companies are able to reduce costs (cost reduction), avoid waste and produce products effectively and efficiently and in the end. can increase profit for the company. 


\section{Characteristics of Total Quality Management}

There are ten characteristics of TQM developed by Goetsch and Davis in Nasution (2005).

1. Focus on the customer. In TQM, both internal and external customers are the drivers. External customers determine the quality of the product or service delivered to them, while internal customers play a major role in determining the quality of labor, processes and the environment associated with the product or service.

2. Obsession with Quality. In organizations that implement TQM, internal and external customers determine quality. With these defined qualities, organizations must be obsessed with meeting or exceeding what they define. This means that all employees at every level try to carry out every aspect of their work from a perspective. How can we do it better? If an organization is obsessed with quality, then the principle of 'good enough is never good applies

3. Scientific Approach. A scientific approach is indispensable in the application of TQM, especially for job design and in the process of decision making and problem solving related to the designed work. Thus, data is needed and used in compiling benchmarks, monitoring performance, and implementing improvements.

4. Long Term Commitment. TQM is a new paradigm in doing business. For that, a new corporate culture is needed. Therefore, long-term commitment is very important in order to make cultural changes so that the implementation of TQM can run successfully.

5. Teamwork (Teamwork). In traditionally managed organizations, competition is often created between departments in the organization so that competitiveness is boosted. Meanwhile, in organizations that implement TQM, teamwork, partnerships and relationships are established and fostered, both among company employees and with suppliers, government agencies, and the surrounding community.

6. Continuous System Improvement. Every product and or service is produced by utilizing certain processes in a system / environment. Therefore, the existing system needs to be improved continuously so that the quality it produces can increase.

7. Education and Training. Today there are still companies that turn a blind eye to the importance of employee education and training. Such conditions cause the company concerned to not develop and find it difficult to compete with other companies, especially in the era of global competition.

However, in organizations that implement TQM, education and training are fundamental factors. Everyone is expected and encouraged to continue learning. By learning, everyone in the company can improve their technical skills and professional expertise.

1. Controlled Freedom. In TQM, employee involvement and empowerment in decision making and problem solving is a very important element. This is because these 
elements can increase employees' sense of belonging and responsibility towards decisions that have been made. Nonetheless, the freedom that arises because of this involvement and empowerment is the result of well-planned and executed control.

2. Unity of Purpose. In order for TQM to be implemented properly, the company must have a unified goal. Thus, every effort can be directed towards the same goal. However, the unity of this objective does not mean that there must always be an agreement / agreement between management and employees, for example regarding wages and working conditions.

3. Employee Involvement and Empowerment. Employee involvement and empowerment can increase the likelihood of making good decisions, good plans, or more effective improvements, because it also includes the views and thoughts of those who are directly related to the work situation and increases 'ownership' and responsibility for decisions by involve the people who have to do it.

\section{Relationship between Total Quality Management and Managerial Performance}

Someone who holds a managerial position is expected to be able to produce a managerial performance, in contrast to employee performance which is generally concrete, managerial performance is abstract and complex. Managers produce performance by directing their talents and abilities, as well as the efforts of several other people who are within their jurisdiction (Mulyadi and Setiawan, 2001).

Companies that implement TQM will produce products that are truly in accordance with customer needs and expectations. So there is no redundancy of work or disposal of raw materials, reduction of overhead costs or reduction of wages. Simplification of the production process and reduction of waste can ultimately improve managerial performance, because the ultimate goal of TQM is company performance that can be achieved through leadership, empowerment and participation of human resources, as well as using process improvement information and analysis. So that the resulting product according to customer needs and expectations. The company's goal in producing quality products is to achieve customer satisfaction, which is marked by reduced complaints from customers so that it can improve company performance..

\section{RESEARCH METHODS}

The method in this research is a qualitative approach. What was done was to review the research location as follows: Jl. Graha Tirta Bougenville 51 Waru Sidoarjo. This was chosen because the Mukmin Mandiri cooperative is one of the production cooperatives whose activities are producing 99 brand coffee. 


\section{Data Collection}

The data collection method is done by:

1. Interview. Is a method of collecting data by asking a respondent something, the way is by having face-to-face dialogue.

2. Observation. It is systematic observation and recording of the elements that appear in a symptom or symptoms in the object of research.

3. Questionnaires. Is an instrument for collecting data in the form of a list of questions or questions submitted to respondents to be answered in writing. Data collection was carried out using primary data and secondary data;

a. Primary data. Primary data is data obtained from direct interviews with employees or employees concerned with a list of questions regarding observations of TQM 99 coffee processing at the Mukmin Mandiri cooperative.

b. Secondary data. Secondary data is data obtained through literature study which comes from personal documents, archives, or official data from related agencies. The data obtained is a profile of 99 coffee products and the Mukmin Mandiri cooperative.

\section{RESULTS AND DISCUSSION}

\section{System and TQM Processing of Coffee Brand Products 99}

This discussion provides an overview of the business processes of the Mukmin Mandiri cooperative in carrying out business activities. All management principles are carried out in a professional manner. In the business planning process, the employees of the Mukmin Mandiri cooperative carry out careful planning.

Starting from human resource planning, production planning, marketing sales planning, to financial planning. HR planning, namely by restructuring the chairman and members of the management to create a special structure in business management. The position of the administrator as a cooperative administrator.

After a special structure was formed, a work program was built and carried out in a professional manner with a proportional division of labor. Employees in the production department, producing quality products according to market needs. Production management is done professionally in terms of taste (taste). Furthermore, employees in the finance and accounting departments. The employees of the Mukmin Mandiri cooperative, managing finances, starting from financing capital, purchasing raw materials for production needs and other costs, to providing incentives for employees are also carried out professionally.

The marketing department encourages professional governance and the value of economic empowerment of the people through cooperation between Islamic boarding schools in East Java. The innovation in the marketing pattern that is being built is that coffee 
products are not only marketed in traditional markets in cities and regions in East Java but also create cooperation programs between Islamic boarding schools in East Java.

Before being marketed, a systemic selection is made for each coffee to identify coffee that does not meet different quality requirements, a taste test is also carried out on the coffee, and it is classified into various brands with the provisions that the coffee product is ready to be marketed. Because the company always maintains customer satisfaction by selling high quality coffee. The following is the application of TQM in various aspects to improve and maintain the quality of the coffee products produced:

\section{Quality Control on Raw Coffee Brand 99}

In a TQM system, in improving and maintaining the quality of coffee products, it must pay attention to the quality of coffee raw materials. Because basically the quality of the raw materials produced can affect the quality of the product, which makes the product ready to compete and survive in both domestic and export markets. Gradually implementing various policies to maintain and increase the quality of coffee raw materials which will later have an effect on product quality, including:

a. Rehabilitation of community coffee with superior clones and intensification supported by coaching the quality of coffee at the farmer level. The orientation of raw materials must meet the following qualifications: productivity, quality, and coffee resistance to pests and diseases.

b. Cooperating in GAEKI with its associates, namely AEKI to carry out coaching and socialization of coffee raw materials which are oriented towards improving the TQM system in controlling the quantity of raw materials. Types of superior quality coffee raw materials produced by the Mukmin Mandiri cooperative.

c. Locations for coffee raw materials are taken from Malang and Jember with a harvest period of 1 year according to the best coffee quality standards. The best coffee beans are red (Red cerry) with $11 \%$ moisture content in the raw state. The TQM process on raw materials can also be done by immersing coffee raw materials into water. If the coffee beans sink, the coffee beans have the best quality compared to the coffee beans that float.

d. Before processing, the raw material for coffee is stored in a storage warehouse for about 2 years to naturally reduce the moisture content and improve the taste of coffee.

e. Standardization of raw materials as a reference for Islamic Boarding Schools Mukmin Mandiri Sidoarjo (Islamic Boarding School for Agribusiness and Agroindustry) in controlling the quality of coffee raw materials, attention must also be paid to maintain the quality of the coffee products produced. The following presents the quality standards of Indonesian coffee based on SNI, as shown in the table: 
Table 1. Coffee Quality Standards Based on SNI

\begin{tabular}{cccc}
\hline Number & Collective Brand & Quality & \multicolumn{1}{c}{ Quality Qequirements } \\
\hline $\mathbf{1}$ & Aekirobusta & 1,2 & $\begin{array}{l}\text { In accordance with SNI for } \\
\text { coffee beans SNI 01-2927- } \\
1999 / 1999\end{array}$ \\
& washedjava & & $\begin{array}{l}\text { In accordance with SNI for } \\
\text { coffee beans SNI 01-2927- } \\
12\end{array}$ \\
Aekiarabica & 1 & $1999 / 1999$ \\
\hline
\end{tabular}

Source: the Mukmin Mandiri cooperative - Sidoarjo

\section{Implementation of TQM in Coffee Products 99}

Producing a coffee product labeled "99". The application of TQM to 99 coffee products that are produced must comply with good quality standards and in accordance with the feasibility of consumption of consumer demand. The TQM system that is implemented in these products is an important reference for raising quality continuously through the evaluation of TQM for the product. Because in TQM, both internal and external customers are drivers to determine the quality of the coffee product.

Implements the TQM system which aims to control the quality of coffee products starting from the quality improvement process so that it is expected to reduce the chances of making mistakes in producing products, because a good product is a product that meets the expectations of customers.

Product design is processed in accordance with procedures and techniques designed to meet customer expectations, as well as the participation of all components in the organization so that they have high motivation and performance in achieving customer satisfaction goals.

In a TQM coffee product processing system "99" applies or observes various provisions regarding quality product control, including:

a. Product design. The design or shape of the product can also affect the quality of the product because consumers or customers first see a quality product with the appearance of the product itself. In a coffee product TQM system, there is one aspect that is very influential on consumers, namely quality control through the distinctive taste of the best coffee. Because coffee is a type of beverage that excels in taste (Taste). The Mukmin Mandiri Cooperative found quality control in coffee, namely conducting experiments for more than 2 years. Finally, a taste is found that suits the tastes of consumers in general. However, the Mukmin Mandiri cooperative must maintain the quality that consumers have trusted because this is 
a distinctive feature of the taste of "99" coffee products. In creating a taste that has the best quality, Pesantren Mukmin Mandiri - Sidoarjo continues to improve the quality of taste, namely by learning and collaborating with other coffee industries to increase the taste that is more classy and preferred by consumers.

b. Market service. In applying the TQM system to a product that is able to meet the needs and satisfaction of consumers in a sustainable manner (sustainable satisfaction) will lead to sustainable purchases which in turn can increase the company's productivity to reach economies of scale with the result of reducing production costs "(Ibrahim, 2000). One of them is seen from the service to the market as well and as a whole. In the Mandiri Mukmin cooperative, in implementing consumer demand services for "99" coffee products in the market, it applies a principle based on Islamic principles, namely building friendship (strengthening brotherhood) with consumers on an ongoing basis. The aim is to get a broad link to consumers so that the Mukmin Mandiri - Sidoarjo cooperative will always have a place in the market.

In addition, the time when the order delivery service by distributors must be on time with the right amount. To increase the number of sales of the Mukmin Mandiri Islamic Boarding School.

\section{Constraints to the Implementation of TQM and the Efforts Made by the Independent Mukmin Cooperative}

A company (large or small) in applying a TQM system to the products it produces, does not always work as desired. The company will definitely experience a constraint that has a big influence on the successful application of the TQM system to the resulting products.

The cooperative experiences various obstacles to the quality of the products produced, including:

1. Constraints that are input, namely the control of raw materials. Raw materials from farmers are still not harvested in 1 year and have been harvested first by the farmers, which is 8 months because they are affected by prices. This will affect the taste quality of the coffee products produced.

2. In the production process, namely machines that are not fully manufactured. Space or a place to produce at the SME or Home Industry level. This will be a problem when market demand soars.

3. Human resources (Santri) even though they have good skills, especially in the production process, are still very small in number, namely 4 people and some of them also do not have a high professional spirit.

4. The resulting product, seen from the perspective of the packaging, still finds a discrepancy in the TQM system, namely there are defective products.

Besides the company also has TQM constraints that can affect product quality, of course the company also has a solution to overcome the various kinds of obstacles that are caused. 
The following is a solution applied by the Mukmin Mandiri - Sidoarjo cooperative in dealing with coffee product TQM problems:

1. Applying understanding to farmers, namely that farmers must change better coffee cultivation methods in increasing quantity and quality through continuous guidance and counseling to provide an overview of the best quality coffee beans during the proper harvest period.

2. In the near future will open a new, larger and more standard production place or house leading to comprehensive manufacturing.

3. To improve product quality through human resource skills, cooperative employees continue to carry out continuous training to increase high professionalism, namely by following interactive lectures every week which are held on Tuesday after prayer, participating in various kinds of exhibitions and seminars on coffee development.

4. In controlling and improving the quality of the products produced, it is always necessary to control gradually to apply the TQM system to products so that they are defect free.

\section{CONCLUSION}

1. Sesuai dengan falsafah bisnis perusahaan yaitu 'sejak awal hanya memproduksi produk-produk bermutu unggul', maka koperasi Mukmin Mandiri sebagai pesantren yang berkembang dibidang usaha kopi 99, memberi perhatian yang sangat besar terhadap sistem Total quality management (TQM). Sistem Total Quality Management (TQM) yang diterapkan pada pengolahan kopi yakni berawal dari pemilihan bahan baku unggul sampai pada proses akhir produksi hingga pada pemasaran produk.

2. Koperasi Mukmin Mandiri, Dalam proses pengolahan berdasarkan system TQM terus berupaya meningkatkan kualitas produk yang dihasilkan. Mulai dari pengendalian mutu pada bahan baku kopi, mutu pengolahan diukur pada poses produksi sampai pada penerapan TQM pada produk kopi yang meliputi desai produk, rasa (taste), dan pelayanan pasar.

3. Koperasi Mukmin Mandiri juga menyadari adanya berbagai macam kendala dan permasalahan yang dihadapi dalam proses TQM pengoalahan produk kopi yaitu Pada proses produksi mesin yang dignakan masih belum sepenuhnya pabrikasi. Ruang atau tempat untuk berproduksi masi bertaraf UKM atau Home Industry.

\section{SUGESSTION}

1. Based on the observations made by the author of the field conditions regarding TQM processing of coffee products, namely the packing process which still uses human 
labor, it is better to use a machine for the packing process. Because by using a machine, the production process can run effectively, so as to improve product quality based on the quantity produced. In addition, using machines can fulfill consumer orders and does not interfere with product marketing services because the production department is a very influential part of the TQM of a company's product processing, and greatly determines marketing.

2. To control TQM in the processing of coffee products, it is better if adjustments are made to market conditions related to consumer tastes, for example taste, product design, and integrated services. Market surveys are carried out in stages within a year to determine the development of consumer tastes and recorded in statistical data as a continuous evaluation of product developments in the market.

3. Based on the obstacles faced by the Mukmin Mandiri Cooperative - Sidoarjo, namely not having TQM data on the processing of coffee products, it is better to make data on TQM continuously as a reference for quality standardization of the coffee products produced. In addition, it is also a reference for evaluating the TQM processing of coffee products in order to maintain the overall quality of coffee, namely from raw materials, production processes, and service to the market. 


\section{REFERENCES}

Abrahamson, E. (1996). "Management fashion." Academy of Management Review. 21(1):254-285.

A.V. feigenbaum, Total Quality control: engineering and Management (New York: McGraw-Hill, 1967), 667 pages

Chenhall, RH (2003) Management control systems design within its organizational context: findings from contingency-based research and directions for the future, Accounting, Organizations and Society 28, pp. 127-168

Hill ,S and A.Wilkinson (1995) In search of TQM. Employee Relations Vol. 17 no. 3 pp. 826

Horine, Julie and Carl Edwin Lindgren (1994). Quality management in 21st century education, Educational Review, Volume 100, Number 7:101-105

J.M. Juran, Leadership For Quality: An Excecutive handbook ( New York : Tehe Free Press, 1989 ), 376 Pages

Karou Ishikawa, What Is Total Quality Control- The Japanese Way (Englewood cliffs, N.J.: Prentice Hall, 1985)

Karaou Ishikawa, Guide to Quality Control (Tokyo: Asian Productivity Organization, 1983)

Prabowo, Sugeng Sugeng Listiyo, Manajemen Mutu Terpadu: Alternatif Untuk Mengembangkan Perguruan Tinggi, dalam EL-JADID: Jurnal Ilmiah Pengetahuan Islam, Vol. 2 No. 4, Januari 2005

Philip B. Crosby, Quality is Free, The art of making quality certain ( new York: new American library, mentor, 1980), 246 pages

Setiawan, H.C.B \& Komara D.K (2020). The Alternative Blue Ocean Strategy: Bagaimana Strategi Perusahaan Industri Kopi Santri Dalam Menghadapi Persaingan Bisnis? Jurnal Riset Entrepreneurship, Vo..3, No. 1, p. 26-32

W. Edwards Deming, Out of the Crisis ( Cambridge : Cambridge unifersity press, 1986), 507 pages 